\title{
DISSECTING IMPLICIT MEANING IN TEMBANG DOLANAN: A DISCOURSE ANALYSIS
}

\author{
Asep Abbas Abdullah[1], Abdul Muhid[2], Rangga Sa'adillah[3]
}

[1]asepabdullah@uinsby.ac.id, [2]abdulmuhid@uinsby.ac.id, [3]rangga@taswirulafkar.ac.id [1][2]Universitas Islam Negeri Sunan Ampel Surabaya, [3]STAI Taswirul Afkar Surabaya

\begin{abstract}
This article uses discourse analysis to examine dolanan songs such as SlukuSluku Bathok, Cublak-Cublak Suweng, Lir-Ilir, Gundul-Gundul Pacul, and Kloso Bedah. The method used in this research is a descriptive qualitative method so that the data can be described as clearly and objectively as possible by the researchers' subjective views. To avoid bias on the validity of the research results, triangulation was carried out by comparing the researchers' interpretations with some supporting literature. The result of this research is that five dolanan songs contain many meanings. The songs offer a deep meaning about the condition of the environment that grows around it to increase the value of character, good behavior, the environment - especially cleanliness, health, and religious life. The character values are conveyed through satire or humor. Dolanan songs have meanings, both explicit and implicit, about this life. These songs are neatly arranged both in terms of structural both physically and mentally. Javanese children's songs contain poetry filled with language games, such as alliteration, assonance, poetry, and rhythm.
\end{abstract}

Keywords: dolanan song, analysis discourse, structuralism, oral literature, wali songo

\section{INTRODUCTION}

In recent years, research on dolanan songs (folk songs) has been carried out, such as Xin Tian You (Traditional Folk Songs of China), Tom Dooley (Traditional Folk Songs USA), Wat Mout Ik Met Zo'n Man (Traditional Folk Dutch Songs), Soran Bushi (Traditional Folk Songs of Japan), this study also discusses dolanan songs. Folklore is a part of the culture that is spread through speech or oral in general and has some characteristics such as (a) born of a society that is innocent, not literate, and traditional, (b) describes the culture of a particular collective property whose creator is unknown, (c) emphasizes more on the aspect of delusion, there are also satires, humor, and educational messages, (4) often describes certain collective traditions. In addition, there are other common characteristics, namely oral literature that reveals many cliche words and expressions and oral literature that has a profound influence (Abrahams, 1972). These are why some people like to call it oral tradition, even though folklore's scope is wider than oral tradition.
Folklore is divided into three major groups based on its type, namely (1) verbal folklore, (2) partly verbal folklore, and (3) nonverbal folklore (Bascom, 1953). The researcher took the object in the first group from the above opinion, point (f) below. Oral folklore is folklore that is shaped as pure oral. The forms (genres) included in oral folklore are (a) folk languages, such as accent, nickname, traditional rank, and title to the aristocracy; (b) traditional expressions, such as puzzles, proverbs, and bywords; (c) traditional questions such as puzzles; (d) folk poetry, such as pantun, gurindam, and poetry; (e) folk proses, legends, and fables; (f) folk songs ("Folklore: an encyclopedia of beliefs, customs, tales, music, and art," 2011). Folk song is one of folklore form consisting of words and songs that are orally spread, has traditional forms, and has many variants (Lomax, 2017; Lomax \& Science, 1968)

Dolanan songs had a close presence in the lives of children. They still sang some of them when they were playing and gathering 
until around the 1990s. Some people, especially those who lived in rural areas as children, certainly have beautiful memories that are not easily forgotten about those dolanan songs. The children happily played while singing dolanan songs in the yard, in the streets, in the school environment, and in the children's gathering places (Lee et al., 2017; Nugrahani, 2012). Dolanan songs are part of traditional children's games. On the sidelines of the game, dolanan songs are often sung. It makes the game's atmosphere more crowded, intimate, beautiful and exciting (Tyagi, 1994). The example of dolanan songs are Menthokmenthok, Kupu Kuwi, Gundhul Pacul, Cublak Suweng, Kate Dipanah, Sarsur Padang Mbulan, Buta Galak, Montor Cilik, Suwe Ora Jamu, lir-ilir, Pitik Jambul, Pitik Tukung, Sluku Bathok, and Jamuran. It can be seen as a part of the inventory of children's dolanan songs produced by ancestors known and presented by children. Since it was often presented on various occasions, children became a part of dolanan songs' lives.

Javanese dolanan songs have a physical effect and deep meaning. Javanese dolanan songs are the symbol and the symbolic process that is continuously interpreted, deciphered, and affects the framework of meaning owned by humans. Dolanan songs are also created with a structure both in terms of rhyme and rhythm. There are some relations between the constituent elements in the entire order. The relation between these elements can be in the form of drama, logic, and time. There is the unit of forming and composition elements in the unit of structure. The forming elements are multiplication, subtraction, and endeavor. Dolanan songs are also a tool to convey the function of public socialism and entrust messages or advice in it, both in the form of songs that sung and movements that performed. It will relate to how far literary values relate to social values and how far literary values are influenced by social values (Jones \& Jones, 1984). Dolanan songs in the Javanese language are Javanese poems that are sung. They are formed by sounds, rhymes, rhythms, dictions, and structured language styles. Dolanan songs have beautiful and poetic sounds every time the children sing them. Javanese language in dolanan songs has rhymes, including intermittent rhymes, hugging rhymes, flat rhymes, and free rhymes.
These rhymes can support dolanan songs sounds poetic. The rhythm or the strains of tone, tempo, meter, and dynamic will strongly support the sonority of the songs. The chosen dictions include denotative and connotative words that are interrelated and support forming lively, communicative, and poetic sentences. The author uses language styles based on sentence structure, including climax, parallelism, antithesis, and repetition. Language styles are based on whether the song's meaning is directly or not, including rhetorical style (hyperbole and paradox) and figurative style (simile and personification). The songs can be more lively and dynamic using these language styles. One of the activities in this study is reviewing oral literature. The object of study is dolanan songs in Java, especially in several villages of Diwek District, Jombang, East Java. These songs were widely used to teach moral education to children (S.A.P., 2018; Wahid \& Saddhono, 2017). As an object of study, the songs are considered oral literature. It is a type of literature that includes all forms of public literary expression and a culture that is orally spread (from generation to generation) and the result of community art that can show some of the identity of its owner. The main identifying characteristics of primary oral literature are (1) it is orally disseminated and considered as cultural expression (2) it was born in a rural community (people who live in the countryside), or literate people, (3) it describes the cultural characteristics of a society, (4) the author is unknown therefore it belongs to the community, (5)it sounds poetic, regular, and repetitive, (6) it is not concerned with facts and truths, it is more emphasis on the imaginary or fantasy aspects accepted by modern society, but oral literature has an important function in society, (7) it consists of several versions, and (8) it uses colloquial containing dialects and sometimes incompletely spoken (Dundes, 1965).

\section{THEORETICAL FRAMEWORK}

Structuralism is the relation between the constituent elements in the whole order. In this case, the relation between the constituent elements can be in dramatic relationships, logic, and time. In other words, some units form their elements and compositions in that structure. The forming elements are 
operational units used for excavation and reduction (Dundes, 1976). Literary work is independent and free from its surrounding influences, both authors and readers (Jones \& Jones, 1984). Based on the explanation above, the concept of structure in literary works prioritizes totality. This notion is reinforced that the structure is purely to dismantle everything that forms literary work (Merrill, 2012). Based on these expert definitions, structuralism is applied in this study of Javanese dolanan songs. Dismantling with the concept of totality that forms Javanese dolanan songs is the basic concept of this structural theory. Structuralism is divided into three stages: a paradigm shift of thinking, a method, and a theory. These mechanisms are the common way in the development of science. Thus structuralism was refined in genetic structuralism, reception, intertextual, and post-structuralism, especially in deconstruction.

Literary structuralism is an approach that emphasizes the elements in (intrinsic terms) literary works. Abrams said that the approaches that emphasize literary work elements are called the structure of Teeuw's literary works (Dundes, 1976). Structural analysis is an important early stage of literary research, but it does not mean that structural analysis is the main objective in literary research.

Structural analysis is the way to analyze the meaning, especially in literary works. Therefore, researchers should not be trapped in structural analysis because the main objective of the research is to examine the meaning contained in a literary work. Therefore, the researcher should analyze the intrinsic elements of literary works before analyzing them from another aspect. The intrinsic element of a literary work is the basis for further analysis, such as psychological, social analysis, and many others. Thus, structuralism can be seen as a literary approach that emphasizes the relationship between the building elements of the literary work in question (Kronenfeld \& Decker, 1979).

Teeuw said that structuralism analysis aimed to disassemble and describe as detailed as possible, with the interrelation and intertwining of all analyzes and aspects of literary works that will produce a holistic meaning (Harle, 1999; S.A.P. et al., 2020).
Structural analysis is not the sum of the constructive elements. It is important to consider the contribution made by these elements to the overall meaning (meaning of totality) in interconnectedness and intertwining. According to Peaget, structuralism contains three main points. First, the whole idea means that the parts or elements adjust to the set of intrinsic rules that determine the whole structure and its parts. Second, the idea of transformation, the structure of the transformation process, allows the formation of new materials. Third, the idea of self-regulated order, which means that it does not require things outside itself to maintain its transformation procedure; the structure is autonomous to other referral systems (Malbon, 1983).

Rhyme is a structure considering that the literary work is a composition of systemic elements, which between the elements occur reciprocal relations that mutually determine. So, the unity in the elements in literary work is a collection of things that stand alone, but also these things are interdependent, interrelated, and interdependent. Thus, the structure cannot stand alone outside the structure (Izzati et al., 2019; Zemlianova, 1974).

The structure contains the main idea that the parts or elements adjust to a set of intrinsic rules that determine both the entire structure and parts intending to uncover and carefully describe the attachment of all the elements of literary works that produce a comprehensive meaning (Farokhah et al., 2018; Propp, 1984).

\section{METHOD}

The method used in this research is descriptive qualitative (Creswell, 2017; Edwards, 1983). This study includes several stages, including conducting field studies in several villages in Diwek District, Jombang, East Java. This early stage is known as preresearch. The pre-research activity was to observe indirectly the research location, namely Diwek District, Jombang, East Java. Indirect observation is carried out by seeking sufficient information through various sources regarding the realistic situation of Diwek District, Jombang, East Java to ensure that this research is feasible to continue. The information being sought is what dolanan songs are played by the people of Diwek District. 
The second stage is to research by making an inventory of dolanan songs in several villages in Diwek District, Jombang, East Java. In tracing the dolanan songs in several villages in Diwek District, we obtained two data maps. The first is primary data, and the second is secondary data. Primary data are the types of dolanan songs played by the people of the Diwek sub-district, such as Sluku-Sluku Bathok, Cublak-Cublak Suweng, Lir-Ilir, Gundul-Gundul Pacul, and Kloso Surgical. The primary data serves as the primary analysis unit, which the author will interpret through discourse analysis. As for secondary data, such as in which village the dolanan song was played, who played it, and when to play it. Secondary data does not play an important role in the results of this study because the main concern in this study is the interpretation of the dolanan song.

The third stage is to conduct a literature search. This third stage is carried out by finding suitable references to support this research. The literature search plays an important role in the interpretation of the dolanan song. Of course, in discourse analysis, it cannot be denied that there is a side of the researcher's subjectivity. According to Eriyanto (2001), it is because discourse analysis is not a causality framework. Conducting discourse analysis is the task of the researcher to provide interpretation. So to avoid the bias of the research results, triangulation is used as an intermediary to test the validity of the research results (Wahyuni \& Maulina, 2020).

\section{RESULTS AND DISCUSSION \\ The Analysis of Structure Sluku-Sluku Bathok}

Structural is an effort to analyze literary works objectively and apart from questions outside the text of literary works. Structural analysis is considered as an autonomous unanimity of meaning and internal coherence. It is due to a harmonious combination between the aspects of form (which is immediately visible if it is visual and immediately easy to hear if it is in the form of audio or formal aspects of rhyme) and the content of the meaning or thematic aspects of rhyme (Lomax, 2017). Literary work is independent, free from the influence of the surroundings that can be both authors and readers. It elucidates that the concept of structure in literary works prioritizes totality (Lachlan et al., 2013).

The structure of the dolanan song is free in its composition that is not related to rules (guru gutra, guru wilangan, and guru lagu), but a little closer, in which the song structure has an overall coherent and rounded meaning. To achieve the overall coherent and complete meaning, the literary work must meet certain conditions, namely (1) the idea of unity, (2) the idea of transformation, and (3) the idea of selfregulation (Wu et al., 2017). The three basic ideas of structuralism can be described as follows: first, a structure must be a unity that round and intact. The parts or elements that make up the structure cannot stand alone. The elements that are related to one another must be related or interrelated. Second, the structure contains the idea of transformation, which means that the structure is dynamic instead of static. The structure can carry out transformational procedures, which means that new materials can be processed. Third, a structure can regulate itself, which means that the structure does not require assistance from external elements to authorize the transformation procedure. It is illustrated in the following data:

\section{Table 1. Transcript of Sluku-Sluku Bathok Song}

\begin{tabular}{lll}
\hline Line & Transcript & Translation \\
\hline $\mathbf{1}$ & $\begin{array}{l}\text { Sluku-sluku bathok } \\
\text { Bathoke ela elo }\end{array}$ & $\begin{array}{l}\text { Swinging heads } \\
\text { His head shook } \\
\text { again and again }\end{array}$ \\
$\mathbf{3}$ & $\begin{array}{l}\text { Si rama menyang } \\
\text { Solo }\end{array}$ & $\begin{array}{l}\text { The father went to } \\
\text { Solo }\end{array}$ \\
$\mathbf{4}$ & $\begin{array}{l}\text { Oleh-olehe payung } \\
\text { mutha }\end{array}$ & $\begin{array}{l}\text { Bring the gift of the } \\
\text { Mutha umbrella }\end{array}$ \\
$\mathbf{5}$ & Makjenthit lolobah & Suddenly moving \\
$\mathbf{6}$ & $\begin{array}{l}\text { Wong mati ora } \\
\text { obah }\end{array}$ & $\begin{array}{l}\text { Dead people do not } \\
\text { move }\end{array}$ \\
$\mathbf{7}$ & $\begin{array}{l}\text { Yen obah medeni } \\
\text { bocah }\end{array}$ & $\begin{array}{l}\text { If they move, it will } \\
\text { scare the people }\end{array}$ \\
$\mathbf{8}$ & $\begin{array}{l}\text { Yen urip golek } \\
\text { dhuwit }\end{array}$ & $\begin{array}{l}\text { If you are alive, } \\
\text { earn the money }\end{array}$ \\
\hline
\end{tabular}

Javanese song or poetry has several types, such as macapat, tengahan, and gedhe. Some of the songs have definite and strict rules in the choice of words because they have a standard that cannot be changed; namely, the number of lines per song or stanza (guru gatra), the number of syllables per line (guru wilangan), and the final sound or end rhyme of each line (guru lagu). The standard is a 
measure of the beauty of the song, so the violation of the standard is considered damaging and lacking the value of its beauty. Therefore, Sluku-sluku Bathok can be considered free forms since it does not follow the standard rule of guru gatra, guru wilangan, and guru lagu.

Sluku-sluku Bathok song can be categorized as purwo kanthi/sajak gagrak lami. It can be identified from guru gatra (lines of each stanza) that it consists of seven lines of each stanza. Each line is arranged by guru lagu and guru wilangan (the end rhyme and the number of syllables) (7-o, 7-o, 7-o, 9-a, 7-a, 7-a, 8-a, 9-i). It can also be seen through its diction. The dictions use everyday language. However, it also uses archaic language that is quite difficult to understand for some people, for example, sluku-sluku, mak jenthit lolobah, and mutha. It is easier to understand for the rest of the dictions. The diction in the Sluku-Sluku Bathok song creates a beautiful imagination because it illustrates the harmony of life between humans and God. Sluku-Sluku Bathok song uses the form of parallelism (there petition of the same words), namely in their petition of the word of bathok in the first and second lines, the word of obah in the sixth and seventh lines, and in the word of yen in the seventh and eighth lines. Therefore, it can be said that the structure is an entire single unit.

The use of colloquial indicates that life will never be separated from God. It can be seen in the words of Bathok sluku bathok ela elo, which means the way of humans remember God in saying laailaa ha illallah (they usually swing their head while citing it). They believe that remembering Allah will relax the nerves in the brain. The order of the words in the song into one unit will cause a different interpretation if it is decapitated or reversed. This song contains some metaphors that make it has several meanings. The interpretation of this song depends on the reader or listener.

\section{Cublak-Cublak Suweng}

Table 2. Transcript of Cublak-Cublak Suweng Song

\section{Lin Transcript Translation}

\begin{tabular}{lll}
$\mathbf{e}$ & & \\
\hline $\mathbf{1}$ & $\begin{array}{l}\text { Cublak- } \\
\text { cublak } \\
\text { suweng }\end{array}$ & $\begin{array}{l}\text { (come on) play guessing } \\
\text { game (a) very important } \\
\text { information }\end{array}$ \\
\hline
\end{tabular}

\begin{tabular}{|c|c|c|}
\hline 2 & $\begin{array}{l}\text { Suwenge } \\
\text { tinggelente } \\
r\end{array}$ & $\begin{array}{l}\text { (actually) (this) important } \\
\text { information (already) } \\
\text { spread everywhere }\end{array}$ \\
\hline 3 & $\begin{array}{l}\text { mambu } \\
\text { ketundung } \\
\text { gudhel }\end{array}$ & $\begin{array}{l}\text { (but, you know) if caught } \\
\text { (this important } \\
\text { information), it will be } \\
\text { expelled/removed/damage } \\
\text { d by people who do not } \\
\text { understand (stupid) }\end{array}$ \\
\hline 4 & $\begin{array}{l}\text { Pak } \\
\text { empong } \\
\text { lera lere }\end{array}$ & $\begin{array}{l}\text { adults who have a lot of } \\
\text { experience/knowledge } \\
\text { (searching with) sorting } \\
\text { (carefully) }\end{array}$ \\
\hline 5 & $\begin{array}{l}\text { Sopo } \\
\text { nggunyu } \\
\text { ndelek ake }\end{array}$ & $\begin{array}{l}\text { the one who (knows surely } \\
\text { will) laugh/laugh (when) } \\
\text { know there are (lies) }\end{array}$ \\
\hline 6 & $\begin{array}{l}\text { sir, sirpong } \\
\text { dele } \\
\text { kopong }\end{array}$ & $\begin{array}{l}\text { the information that is } \\
\text { considered true (in } \\
\text { general) now is a lie }\end{array}$ \\
\hline 7 & $\begin{array}{l}\text { sir, sirpong } \\
\text { dele } \\
\text { kopong }\end{array}$ & $\begin{array}{l}\text { the information that is } \\
\text { considered true (in } \\
\text { general) now is a lie }\end{array}$ \\
\hline 8 & $\begin{array}{l}\text { sopo nguyu } \\
\text { ndelek ake }\end{array}$ & $\begin{array}{l}\text { If you are alive, earn the } \\
\text { money }\end{array}$ \\
\hline
\end{tabular}

Cublak-cublak suweng uses a more archaic language. This song is classified as sekar dolanan laras slendro, constructed on eight lines with syllables and rhymes of 6-e, 7e, 7-e, 7-e, 9-e, 7-0, 7-0, produces the rhythmic alliteration and make it look neat and well arranged. All of the sentences support and relate to each other. The sentence structure is coherent and cannot be separated from one another without linking the other elements. The composition of the words cannot be changed. If it is changed, the changing will change the meaning of the whole sentence. The author had deeply thought about the composition of the words considering that if we change the order of the words, the harmony of the melody will be decreased. For example, if the sentence of /Suwenge tinggelenter/is replaced by /tinggelente rsuwenge/, the beauty of the sound will decrease, and the meaning will also change. Each of these sentences forms a musical sound to become melodious, called rhyme as phonetic form. If the phonetic form is integrated with the rhythm, it will reinforce the meaning (Solihati et al., 2013). Even though they seem to pay less attention to rhymes, there is a harmony between the appearance of sounds / $\mathrm{u} /$ and sounds / e / in lines 1-2.

The presence of these sounds is also a cohesive use of sounds in the sounds of / o /, / 
e /, and / ng /, which affect the rhythm in the alliteration of the parallelism seen in lines 6-7.

The appearance of these sounds is not just a pattern of poetry, but it has a poetic effect and emphasizes its rhythmic structure. It also puts additional stress on the words concerned and the rhythm harmony.

\section{Lir-Ilir}

Table 3. Transcript of Lir-Ilir Song

\begin{tabular}{|c|c|c|}
\hline Line & Transcript & Translation \\
\hline 1 & Lir-ilir, lir-ilir & $\begin{array}{l}\text { Faintly awake } \\
\text { (from sleep) }\end{array}$ \\
\hline 2 & tandure wis sumilir & $\begin{array}{l}\text { Trees have started } \\
\text { blossoming, }\end{array}$ \\
\hline 3 & $\begin{array}{l}\text { Tak ijo royo-royo } \\
\text { tak senggo } \\
\text { temanten anyar }\end{array}$ & $\begin{array}{l}\text { So verdant like a } \\
\text { newlywed passion }\end{array}$ \\
\hline 4 & $\begin{array}{l}\text { Cah angon-cah } \\
\text { angon penekno } \\
\text { blimbing kuwi }\end{array}$ & $\begin{array}{l}\text { Shepherd child, } \\
\text { please climb the } \\
\text { star fruit tree }\end{array}$ \\
\hline 5 & $\begin{array}{l}\text { Lunyu-lunyu yo } \\
\text { penekno kanggo } \\
\text { mbasuh dodotiro }\end{array}$ & $\begin{array}{l}\text { Although slippery } \\
\text { (difficult), please } \\
\text { keep climb to wash } \\
\text { clothes }\end{array}$ \\
\hline 6 & $\begin{array}{l}\text { Dodotiro-dodotiro } \\
\text { kumitir bedhah ing } \\
\text { pinggir }\end{array}$ & $\begin{array}{l}\text { Torn clothes (bad) } \\
\text { were put aside }\end{array}$ \\
\hline 7 & $\begin{array}{l}\text { Dondomono } \\
\text { jlumatono kanggo } \\
\text { sebo mengko sore }\end{array}$ & $\begin{array}{l}\text { Sew, fix it to face } \\
\text { this afternoon }\end{array}$ \\
\hline 8 & $\begin{array}{l}\text { Mumpung padhang } \\
\text { rembulane } \\
\text { mumpung jembar } \\
\text { kalangane }\end{array}$ & $\begin{array}{l}\text { While the moon is } \\
\text { bright }\end{array}$ \\
\hline 9 & $\begin{array}{l}\text { Yo surako... surak } \\
\text { hiyo... }\end{array}$ & $\begin{array}{l}\text { While there is } \\
\text { plenty of free time }\end{array}$ \\
\hline
\end{tabular}

Literary work that is related to the views of life can be called Sastra Piwulang. Javanese people use it as a guideline for living. There are some expressions about wisdom in the Javanese Ancient Book that aim to create harmony and balance life. One of the media in delivering the wisdom and religious teachings is the Lir-ilir song written by the saints (Wali Songo). This song is one of the cultural products that has orally spread from generation to generation. Lir-ilir is the most frequently sung song that consists of nine lines with rhythmic diction. The verse begins with "lir-ilir," which means a call to be aware, alive, and conscious (Nugrahani, 2012). The use of words in this song is aesthetic dictions since it has both textual meaning and contextual meaning, which occurred at that time. The phrase lir-ilir is chosen to describe a breeze in
Java. The author used tactile imagery of the wind that gently blows.

The second line-tandure wus sumilir, takijo royo-royo tak senggo temanten anyaralso has the same rhyme, which is /ir/,/ir/ the first line. Tandure wus sumirlir, tak ijo royoroyo means the new greeny plants compared with temanten anyar. Tak senggo temanten anyar means as a newlywed couple. It uses figurative language, especially metaphor, that symbolizes the transformation of the kings in the Majapahit kingdom who converted to Islam (Veronika et al., 2017). It can be defined as rebirth in new life. Cah angon cah angon penekno blimbing kuwi symbolizes the king as the shepherd considering that his livestock always follows the shepherd. It is similar to the king, who will always be followed and obeyed by his people. Penekno blimbing kuwi means a suggestion always to do the five pillars of Islam. Blimbing means star fruit that has five angles. Star fruit is juxtaposed with the five pillars of Islam. Then, it is followed by the adverb of lunyu-lunyu penekno kanggo mbasuh dodotira and continued with dodotiro dodotiro, kumitir bedah ing pinggir, which means the cloth begins to tear at its edges. It is the metaphor of the cloths or blankets used by the kings in Java. In Indonesian, the word agama (religion) is cultural acculturation and translated into Javanese as ageman (dodotiro). It can be defined as the perfect religion by climbing the star fruit tree (doing the five pillars of Islam). Dondomono jlumatono kanggo sebo mengko sore means sewing and patching before the sun sets in the west (do the five pillars of Islam perfectly before the time to die comes to you) so that you have enough provision for judgment day. Mumpung padhang rembulane, mumpung jembar kalangane means while there is still a chance, there is still plenty of time, so let us improve ourselves. The last line yo surako surak hiyo, means welcome with cheers or happy hearts. The author uses many metaphors in this song. The lyrics are full of beautiful lyrics and have deep textual and contextual meanings.

The sounds used in data (3) such as / o / in the word of penekno, / ir / in the word of pinggir, and the sound / o / in the word of jlumatono indicate the command. It is in line with the use of dominant ending sounds in / o /, and, / e /, which emit contrast effects. Words arranged in such coherent and harmonious 
sounds create an atmosphere of joy and command, which strongly supports the subject matter expressed by the author.

\section{Gundul-Gundul Pacul}

Table 4. Transcript of Gundul-Gundul Pacul Song

\begin{tabular}{lll}
\hline Line & Transcript & Translation \\
\hline $\mathbf{1}$ & $\begin{array}{l}\text { Gundul-gundul } \\
\text { pacul..cul }\end{array}$ & $\begin{array}{l}\text { A bald head } \\
\text { without hair is like } \\
\text { a hoe }\end{array}$ \\
& $\begin{array}{l}\text { Nyunggi-nyunggi } \\
\text { wakul..kul, } \\
\text { gembelengan } \\
\text { Wakul ngglimpang, } \\
\text { segane } \\
\text { sakratan dadi }\end{array}$ & $\begin{array}{l}\text { The basket fell, the } \\
\text { rice spilled apart } \\
\text { on the road and no } \\
\text { longer useful }\end{array}$ \\
& $\begin{array}{l}\text { Wakul ngglimpang, } \\
\text { A dadi } \\
\text { segane bald head } \\
\text { sakratan }\end{array}$ & $\begin{array}{l}\text { without hair is like } \\
\text { a hoe }\end{array}$ \\
\hline
\end{tabular}

Gundul-gundul pacul song gives philosophical meaning about the value of goodness in this life conveyed by the saints (Saputra, 2016). Although the author is unknown, the song carries a joyful atmosphere and has a deep meaning. The diction of this song is continuous and cannot be separated from each other. The words are easy to understand as it uses colloquial language. However, it also uses figurative language. This song has six lines in one stanza. The arrangement of lines into one stanza seems to be quite dominating the whole song. This song concerns the rhyme, especially the end rhymes, to form a melodious rhythm. It is evident in the whole line that ends with the sound / $\mathrm{n} /$. The order of the number of words is in tune with the order of the final sounds in each line. The rhyme contained in the song is very harmonious. It can be seen from the alliteration of / u / in the sentence "gundul-gundul pacul-

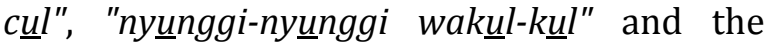
assonance of / e / and / $\mathrm{n} /$ in the sentence "gembelelengan"and"pẹtentengan".

\section{Kloso Bedah}

Table 5. Transcript of Kloso Bedah Song

\begin{tabular}{|c|c|c|}
\hline Line & Transcript & Translation \\
\hline 1 & E, dayohe teko & $\begin{array}{l}\mathrm{E} \text {, the guest is } \\
\text { coming }\end{array}$ \\
\hline 2 & E, jerengno kloso & E, spread the mat \\
\hline 3 & E, Klosone bedah & $\mathrm{E}$ the mat is torn \\
\hline 4 & E, tembelen jadah & $\begin{array}{l}\text { E patch with the } \\
\text { jadah }\end{array}$ \\
\hline 5 & E, jadahe mambu & $\begin{array}{l}\text { E the jadah is } \\
\text { smelly }\end{array}$ \\
\hline
\end{tabular}

\begin{tabular}{lll}
\hline $\mathbf{6}$ & E, pakakno asu & E feed the dog \\
$\mathbf{7}$ & E, asune mati & E the dog is dead \\
$\mathbf{8}$ & E, guwaken kali & $\begin{array}{l}\text { E, throw it into the } \\
\text { river }\end{array}$ \\
\hline
\end{tabular}

The author gives a concrete picture of the relation between the linguistic structure and the structure of meaning of the Javanese song by showing the interrelations between lines to support the combination between language and meaning.

Kloso Bedah's song has free structure, but it can form rhyme which is assonance and alliteration. It can be seen from the rhymes in the last word for each line, such as the same sound / o / in the first and second lines, the same sound / $h$ / in the third and fourth lines, the same sound / $u$ / in the fifth and sixth lines, and the same sound / i / in the seventh and the last lines. Thus, it forms the continuous lines between its linguistic structure and its meaning.

\section{The Analysis of Meaning Sluku-Sluku Bathok}

The song of Suklu-sluku Bathok has the meaning that life should not be spent only on work. We also have to rest to balance life (Inayati \& Millah, 2016; Nugrahani, 2012).

The meaning analysis is presented in table 1, line 1. Bathok means the head. The head should take a rest in order to optimize its work. If the head is overused, we will get stressed and tired.

Analysis of the meaning is presented in table 1, line 2. Ela-elo has the same meaning as laailaa ha illallah. Taking a rest for a while can be done by remembering God (Allah) since it will relax the nerves in the brain. Si ramamenyang solo means we should take a shower or ablution (wudhu) and continued with solo (sholat) praying.

Analysis of the meaning is presented in table 1 , line 4 . It can be defined that if we are praying (sholat), we will get protection (payung means umbrella) from God (Allah). If God has protected us, nothing will damage or hurt us.

Analysis of the meaning is presented in table 1 , line 5 . It means that death will suddenly come to us. No one knows the exact time when it will come. So, we must always be prepared by doing good deeds as our provision on judgment day. 
Analysis of the meaning is presented in table 1 , line 7 . It means that when death comes, we have no more chance to do good deeds. Many people want to be revived to do good deeds, but God does not allow it, considering that it will be frightening and will harm others if the corpse is alive again.

Analysis of the meaning is presented in table 1 , line 8 . It means that the present time is the best time for working and doing good. It can be done by earning money, helping the other, and making the parents happy. It will be better if our wealth can contribute to the upholding of Allah's religion.

\section{Cublak-Cublak Suweng}

The word of cublak is a customary word or idiom used for a game of mutual guessing, while the word suweng means ear ornament (not an earring or ear stud) hung on the earlobe (Solihati et al., 2013). It is the idiomatic word for important information. It is stated in the song that it can be translated as "let us play guessing game (a piece of very important information).

Analysis of the meaning is presented in table 2, line 2. As explained above, suweng means important information. Tinggelenter means scattered. These two combined words mean the scattered information in some places.

Analysis of the meaning is presented in table 2, line 3. Mambu means to be smelled, while ketundung means to be driven out or to be removed. Gudhel means a buffalo child, but gudhel is also an idiom word that means a fool person. Buffalo is very useful for farming, but it is different for a buffalo child since the buffalo child only likes to play and eat (it still cannot be used for farming). So, the meaning of mambu ketundung gudhel is "if you caught out, you would be expelled/removed/damaged by the people who do not understand (the fool one).

Analysis of the meaning is presented in table 2, line 4. Pak empong is the idiom of adulthood or maturity because empongor ompong means toothless for mentioning the elders. Pak is the appellation for the older man (similar to Sir) that indicates the adult. So, the words of pakempong refer to "the adult because he has much experience." After that, leralere means turned the head to left or right/choose. From the explanation above, it can be said that the meaning of pakempong leralere is "adults who have much experience (searching with) sort out (carefully)." In other words, it can be defined.

Analysis of the meaning is presented in table 2, line 5. Sopo nggunyu ndelek ake means "the one who laughs, he (surely) hides." Its meaning is similar to "the one who laughs surely knows there are (lies)." In other words, it can be defined that "the one who (knows will exactly) laughs when knowing that there is (lie) there.

Analysis of the meaning is presented in table 2, lines 6-7. Sir, pong means the empty ball that does not contain anything, while dele kopong means soy floating on the water since it does not contain anything in it (something that is considered a big thing is nothing in it). Its meaning is similar to "the information considered as true information nowadays is a lie."

\section{Lir-Ilir}

The word of Lir-ilir comes from the Javanese word of Ngelilir, which means wake up from sleeping. People who have not converted to (Islam) are said to be still sleeping or unconscious. In the words of Lir-ilir, Lir-ilir (repeated twice), the meaning is "wake-up," wake up to a new realm of thought, namely Islam. Table line 2 line consists of tandure, which means seed planted. Wis sumilir means it has grown. So, the line of tandure wis sumilir can be defined as the seed that planted has begun to grow. The seed here means faith, namely Islamic faith (Rabimin, 2009; Wahid \& Saddhono, 2017).

All human beings have been given the seed of faith by God. It depends on the people whether they are "aware" of this "seed" or not. If a person is "aware" of the seeds in himself and wants to take good care of each day, the seed will flourish and produce good fruit.

The lyric's meaning is presented in table 3, line 3. Tak Ijo Royo-Royo means "made to flourish, fresh green leaves." The meaning of the sentence seems to emphasize the "appearance" of a pleasant Muslim personality. A seed of faith that is always cared for makes the Muslim physically and mentally healthy. Ijo-royo-royo is a symbol of fertile plants because it is well planted. Pengantin anyar means the newlywed couple (the bride and the groom). This analogy is attributed to humans for their faith who have only just met as the newlywed couple. The newlywed is the people 
who are very happy in their new life. So, Tak sengguh pengantin anyar means people who strongly believe in Islam. So, the meaning of Tak ijo royo-royo is the seed of faith of someone who is well cared for will produce a good Muslim too. The happiness of a Muslim here is like the newlywed. A solid faith that is described above must always be maintained and cared for properly. Plants can no longer become tak ijo royo-royo when exposed to pests. We can associate this analogy with the faith of a Muslim. Maintaining the faith to remain strong must dispel the pests (example: gambling, stealing, adultery, drinking alcohol are like the "pests" of faith that must be eradicated immediately).

Analysis of the meaning is presented in table 3, line 4. Cah Angon means shepherd's child. The words are repeated even twice, which means that there is an emphasis or an important command. The command is peneken blimbing kuwi or climbs the star fruit tree. This order is given to the one who is in the higher position to the lower positions. This analogy means the parents who rule their child. The shepherd must have livestock (followers). Humans, like the shepherds, must guide their lust. If lust is not guided well, it will damage and certainly violate many religious orders or rules. The human must be able to act as a good shepherd. Cahangon is a representation of a Muslim who becomes a shepherd of his lust.

Peneken blimbing kuwi. The people asked to climb the star fruit tree (to get the fruit). The word of star fruit is used as an example because the star fruit has five sides which refer to the picture of the pillars of Islam.

Analysis of the meaning in table 3 line 5 Lunyu - Lunyu yo Peneken means "even though it is slippery, keep climbing" (this line is related to the previous line (cah angon-cah angon, peneken blimbing kuwi). A slippery tree is an obstacle for the climber, so he must climb it carefully, avoiding slipping down, which is the same with religious orders. If it is not taken seriously, it will slip you into hell. The way to get in hell is easier than the way to get into heaven. However, God's command to climb the star fruit tree is not a burden and not something heavy for the obedient like cahangon (to reach a delicious fruit, namely heaven).

Kanggo mbasuh dodot iro. That sentence has the purpose of cleansing or purifying beliefs until they truly become sacred beliefs. Dodot is oversized clothing in the palace in which, in this context, serves as an analogy to the belief. During the Wali Songo era, many people embraced Hinduism, Buddhism, and Animism. These beliefs were washed with Islamic faith by Wali Songo to become a pure and true religion, namely Islam. One of the cleaners is the Five Pillars of Islam.

Analysis of the meaning in table 3 line 67. The previous explanation tells that dodot is used to describe religion or belief. Kumitir bedah ing pinggir means that it is torn in the edges. The command of dondomono jlumotono, which follows it means sewn or repaired. Damaged clothes should be repaired so that they are suitable to wear again. It is related to religion. If it is corrupted (because of the sins that have been committed), it should be corrected by asking Allah for forgiveness (repentance) and doing the pillars of Islam as well as possible.

Kanggo seba means come, face the Almighty, God. Whereas sore means afternoon that also can be defined as the end of the journey, especially the human journey in the world. So, the purpose of Kanggo sebo mengko sore is to make the people ready to face God later when the journey of life is over.

Analysis of the meaning is presented in table 3, line 8. Mumpung padang rembulane, mumpung jembar kalangane means while the moonlight is bright, while its light is broad. It will be very dark and make the people unable to see anything without the moonlight at night (without any lighting). It means that when it is dark, people will find it difficult (even unable) to distinguish between which one is good or right and which one is bad or wrong. However, there is a "ray of light" in that dark atmosphere from the light of the moon (Islamic Light) so that it can be clear which one is good and which one is bad.

Mumpung jembar kalangane means wide moonlight coverage will be able to illuminate large areas. So, mumpung padang rembulane intends to remind the people that there is still a chance to reach heaven (to seek star fruit) or carry out religious orders, namely the five pillars of Islam. Because of the existence of Islamic Light, people can distinguish which one is right and wrong. Therefore, good opportunities should not be wasted away. All of 
that is an invitation for all mankind to carry out the five pillars of Islam properly and correctly.

Analysis of the meaning is presented in table 3, line 9. The line above (let us cheer, cheer) is an invitation to be happy since the human (Muslim) can accomplish the order of religion to obtain the five pillars of Islam. Being happy is a gift or reward from his work of "climbing the star fruit tree" or (heaven).

\section{Gundul-Gundul Pacul}

Gundul (in table 4, line 1) means bald. In general, that hair is the crown of the head, the gift from God that adds to the charm and beauty of His creatures named humans (Saputra, 2016). Therefore, it is very ironic if the hair that is supposed to be the crown of the beauty of the head does not exist. Based on the statement above, it can be understood that many people are afraid of hair loss, especially women. The word of gundul is accompanied by the word of pacul, which means a hoe. It can be seen the difference between these two words that have no connection between one to another. The word of gundul associated with the human head, a symbol of honor and glory, is juxtaposed with pacul, a tool for hoeing the rice field. However, this is very reasonable for Javanese people, especially in rural areas where most of their livelihoods are farmers; they like to take the parables with everyday items with their world, for example, pacul (hoes). Javanese feel proud and honored with their work as the farmers with their agrarian culture. The word bald, which means head without hair, is strengthened or likened to a hoe, a plain rectangular iron or steel plate without decoration. The head symbolizes human glory and honor because there is a brain or a place of human reason in it, which is the greatest gift from God that is not given to His other creatures.

In the Javanese language, the word "hoe" means papat kang ucul (four loose things), similar to the shape of a rectangular hoe. It means that the glory and honor of a person depend on what is available and done by the head and its contents. The brain is the most vital organ of the head since it is the place of the mind that affects all human movements and actions. In addition, there are still four other organs in the head that become warriors of reason, namely the eyes, nose, ears, and mouth, which if they were released ("ucul") from the control of the mind; rationality will do as they wish.

Gembelengan (in table 4, line 2) the deeds symbolized by the head are besar kepala (arrogant) and keras kepala/kepala batu (stubborn). Some of these expressions reflect someone arrogant, stubborn, and feels better than the others, which Javanese symbolizes "Gembelengan." In other words, it can be described as they walk with their chest puffed up, raise their head, feel themselves the greatest, and look on others down.

So, "Gemblengan" is the attitude of someone whose mind cannot control the four senses in the head (eyes, nose, mouth, and ears). It is like "pacul" or papat kang ucul (four things that lose). Consequently, his honor and dignity are lost since no longer a crown of beauty radiated from his head. His eyes are used to look at things that cause immorality and sin. The ears no longer want to listen to wisdom and benevolent advice from elders or parents. The nose no longer functions to smell the fragrance, and he uses it to sin. The mouth is no longer speaking of virtue or amar ma'ruf nahi munkar; he uses it to gossip, slander, and lie. These attitudes make people arrogant as their four sense in their head has gone out of control.

\section{Kloso Bedah}

Dayah eteko (in table 5 line 1) the guest came (indicating a problem). Since they were confused, they were immediately put a mat on the floor (the problem was partly solved). It turned out that the mat was torn; it was also immediately decided to be patched with "jadah" in table 5 , line 5 (solved without discussion first). It unexpectedly found that "jadah" smelled foul/ "jadahe mambu" and it makes the guest "mites"/cover their nose with their hands. Because of embarrassment without deep thinking or discussion with the other people, "jadah" was given to the dog/ "asu" in table 5, line 6. This solution turned out to be a big mistake because "jadah" contained poison.

As a consequence, his beloved dog died. Then, the dog was immediately thrown/"dikelekke" to the river without any discussion with the others anymore. Thus, the river was automatically poisoned. The people started to think that everything that was not 
useful or the garbage could be thrown into the river and made the river was full of garbage.

\section{The Analysis of Function Sluku-Sluku Bathok}

Society life and human culture are very significant in communicating with the social environment. In Islamic belief, humans are the leaders on earth, which means they have the main task of developing and spreading the religion of God. Therefore, the existence of humans has an important role in penetrating the gaps in a civilized society to lead them to Islam.

The functions of Suklu-suklu Bathok song are (1) considered as a form of entertainment, (2) considered as the educational medium for the community members, (3) providing social sanctions in order to make the people behave well, (4) considered as enforcers and regulators so that the social norms and God always obeyed.

As an entertainment function, this song can entertain the people during the pressure of doing their works. As the education medium both for the children and the adults, it can be as enforcers and regulators so that the social norms and God always obeyed as stated in the song at table 1 line 1-2. People are expected to remember God whether in their busy time or in their spare time. It has deep meaning because the singer or listener can recognize and determine how often they remember God.

\section{Cublak-Cublak Suweng}

Cublak-cublak Suweng song, which is filled with physical structure requirements-in the form of sound rules-is also filled with mandates as its characteristic. The functions of Cublek-cublek Suweng song are (1) considered as a form of entertainment, (2) considered as the educational medium for children, (3) providing social sanctions so that people behave well and honestly (Solihati et al., 2013).

As entertainment, Cublek-cublek Suweng song gives the joy that produces satisfaction in children's games during leisure time to eliminate resentment, fatigue, and boredom. The function of Cublek-cublek Suweng song as the educational medium for the children in order to make them behave well and honestly is based on the translation of this song, "adults have a lot of experience/ "knowledge" (searching by) sorting (carefully)." From the quotation above, the children are expected to look for the experience or knowledge carefully and become honest as the provision for the future.

\section{Lir-Ilir}

The functions of Lir-ilir song are (1) considered as the educational medium for the community members, (2) considered as a form of entertainment, (3) providing social sanctions in order to make the people behave well, (4) considered as social criticism. Lir-Ilir's song gives a sense of optimism to someone doing good deeds that will be very useful for provision in the judgment day. The opportunity to live in this world must be utilized to do good, considering that every deed will reward. The song also applies as an art form, an indirect delivery means, and social functions considering that we, as an active heir of the oral tradition and as the reader, should preserve the song.

As the educational medium, the Lir-ilir song presents a religious theme described through its sentences, and the author is Wali. Therefore, the collective members (the people who sing or listen to the song) feel that the song contains religious values and commands. Moreover, its collective members can feel the education function in the Lir-ilir song since they are aware of their shortcomings or mistakes while listening or singing this song. At the same time, the entertainment function of a person who is singing or listening on the sidelines of empty time or rest can eliminate resentment, fatigue, and boredom after doing his activities. In addition, this song also functions as a tool to grow and strengthen the sense of confidence to look for the meaning of life.

\section{Gundul-Gundul Pacul}

The functions of Gundul-gundul Pacul song are (1) considered as the educational medium for the community members, (2) considered as a form of entertainment, (3) providing social sanctions in order to make the people behave well, (4) considered as social criticism (Nugrahani, 2012; Saputra, 2016). The song in Javanese society has commercial value and reflects the character of Javanese society, both its culture and social conditions. As the educational medium, the song teaches the people the moral value of being humble and 
polite to other people to build a good relationship (Muhid et al., 2018). As the educational medium for children, the song suggests the parents teach their children to become good people by being humble even though they have some advantages compared to others.

\section{Kloso Bedah}

The functions of Kloso Bedah song are (1) considered as a form of entertainment, (2) providing social sanctions in order to make the people behave well, (3) considered as enforcers and regulators so that the social norms and God always obeyed. It especially discusses how people should not resolve the problem quickly in avoiding getting any new problem.

\section{CONCLUSION}

Based on the study results, it can be concluded that these five Javanese songs contain many meanings. Dolanan songs entertain the people and offer a deep meaning about the environmental conditions that grow around it to raise the values of character, good manners, and the environment-especially cleanliness and health-and religious life. It can be delivered through satire or humor. Dolanan songs have, either explicit or implicit, meaning about this life. These Dolanan songs consciously or unconsciously introduce a sense of beauty and literature. These songs are neatly arranged in terms of structure, both physically and mentally. Javanese children's songs contain poetry full of language games, such as alliteration, assonance, rhyme, and rhythm.

\section{REFERENCES}

Abrahams, R. D. (1972). Folklore and literature as performance. Journal of the Folklore Institute, 9(2/3), 75-94.

Bascom, W. R. (1953). Folklore and anthropology. The Journal of American Folklore, 66(262), 283290.

Creswell, J. W. (2017). Research Design (Keempat). Pustaka Pelajar.

Dundes, A. (1965). The study of folklore in literature and culture: Identification and interpretation. The Journal of American Folklore, 78(308), 136-142.

Dundes, A. (1976). Structuralism and folklore. Studia Fennica, 20(1076), 75-93.

Edwards, C. L. (1983). The Parry-Lord theory meets operational structuralism. The Journal of American Folklore, 96(380), 151-169.

Eriyanto. (2001). Analisis wacana: pengantar analisis teks media. LKiS Yogyakarta.

Farokhah, F. A., Habsari, S. K., \& Mugijatna, M. (2018). Pseudo-Beauty: Sexuality in Indah Hanaco's the Curse of Beauty (a Study of Critical Discourse Analysis). LiNGUA: Jurnal Ilmu Bahasa Dan Sastra, 13(1), 1. https://doi.org/10.18860/ling.v13i1.4877

Harle, P. (1999). Structuralism. Department of Folklore and Ethnomusicology, Indiana University.

Inayati, K. F., \& Millah, A. S. (2016). Islamic Education and Multiple Intelligence Implementation in Traditional Game of Sluku-Sluku Bathok at Komunitas Pojok Budaya, Bantul of Yogyakarta. Jurnal Pendidikan Islam, I(1), 22.

Izzati, N., Djatmika, \& Santosa, R. (2019). Grammatical Intricacy Dalam Cerita Pendek Karya Penulis Anak Indonesia. LiNGUA: Jurnal Ilmu Bahasa Dan Sastra, 14(1), 213. https://doi.org/10.18860/ling.v14i1.6710 
Jones, S. S., \& Jones, G. (1984). Folklore and literature in the United States: an annotated bibliography of studies of folklore in American literature (Vol. 5). Scholarly Title.

Kronenfeld, D., \& Decker, H. W. (1979). Structuralism. Annual Review of Anthropology, 8(1), 503-541.

Lachlan, R. F., Verzijden, M. N., Bernard, C. S., Jonker, P.-P., Koese, B., Jaarsma, S., Spoor, W., Slater, P. J. B., \& ten Cate, C. (2013). The progressive loss of syntactical structure in bird song along an island colonization chain. Current Biology, 23(19), 1896-1901.

Lee, K. S., Bahri, S., Murugiah, M. K., Adenan, M. A., Khan, T. M., Nasir, M. A. M., \& Ming, L. C. (2017). Folk songs for health education: Implementation and qualitative evaluation. Research in Social and Administrative Pharmacy, 4(13), 36.

Lomax, A. (2017). Folk Song Style and Culture. Routledge.

Lomax, A., \& Science, A. A. for the A. of. (1968). Folk song style and culture (Vol. 88). Transaction Publishers.

Malbon, E. S. (1983). Structuralism, hermeneutics, and contextual meaning. Journal of the American Academy of Religion, 51(2), 207-230.

Merrill, J. E. (2012). The Role of Folklore Study in the Rise of Russian Formalist and Czech Structuralist Literary Theory. UC Berkeley.

Muhid, A., Asnawi, \& S.A.P., R. S. (2018). Pendidikan Moral Melalui Pembelajaran Kitab Alfiyah Ibn Malik di Pondok Pesantren Langitan Tuban. Jurnal Pendidikan Agama Islam (Journal of Islamic Education Studies), 6(1), 106-126. https://doi.org/http://dx.doi.org/10.15642/jpai.2018.6.1.106-126

Nugrahani, F. (2012). Dolanan jawa dalam rangka pembentukan karakter bangsa (kajian semiotik). Kajian Linguistik Dan Sastra, 24(1), 58-68.

Propp, V. I. (1984). Theory and history of folklore (Vol. 5). Manchester University Press.

Rabimin. (2009). Makna Lagu Donan Ilir-Ilir. Gelar: Jurnal Seni Budaya, 7(2), 149-162.

S.A.P., R. S. (2018). Pemikiran Pendidikan Karakter Al-Ghazali, Kohlberg dan Thomas Lickona. In Memperbincangkan Pemikiran Pendidikan Islam dari Idealisme Substantif Hingga Konsep Aktual (1st ed.). Prenadamedia Group. https://books.google.co.id/books?id=H8BjDwAAQBAJ\&printsec=frontcover\&hl=id\#v=onepa ge\&q\&f=false

S.A.P., R. S., Tobroni, Ishomuddin, \& Khozin. (2020). The Meaning Construction of a Scientific Approach on Teaching Islamic Education. International Journal of Psychosocial Rehabilitation, 24(09), 2525-2532. https://doi.org/10.37200/IJPR/V24I9/PR290284

Saputra, M. I. (2016). Pemimpin Ideal dalam Perspektif Syair Gundul-Gundul Pacul. Al-Tadzkiyyah: Jurnal Pendidikan Islam, 7(November), 299-311.

Solihati, N., Himat, A., Jupri, A. R., \& Hidayatullah, S. (2013). Nilai Pendidikan Karakter dalam Permainan Rakyat di Lereng Gunung Merapi. Journal of Petrology, 369(1), 28-42. https://doi.org/10.1017/CB09781107415324.004

Tyagi, S. (1994). Counternarrative strategies: An analysis of women's folk songs from northern India. 
Veronika, P., Setiawan, B., \& Wardani, N. E. (2017). Implementasi Pembelajaran Bahasa Jawa (Materi Tembang Dolanan) Berbasis Pendidikan Karakter Religius Dalam Kurikulum 2013. ElHARAKAH, 19(1), 53. https://doi.org/10.18860/el.v19i1.3929

Wahid, A. N., \& Saddhono, K. (2017). Ajaran Moral Dalam Lirik Lagu Dolanan Anak. MUDRA Jurnal Seni Budaya, 32(2), 172-177. https://jurnal.isidps.ac.id/index.php/mudra/article/view/107/50

Wahyuni, D., \& Maulina, Y. (2020). Maintaining the Self-Existence Through Short Story "Jalan Sumur Mati." LiNGUA: Jurnal Ilmu Bahasa Dan Sastra, 15(2), 149-162. https://doi.org/10.18860/ling.v15i2.9156

Wu, F., Song, G., de Graaf, C., \& Stevens, R. C. (2017). Structure and function of peptide-binding G protein-coupled receptors. Journal of Molecular Biology, 429(17), 2726-2745.

Zemlianova, L. M. (1974). Structuralism and its most recent modifications in current American folklore studies. Soviet Anthropology and Archeology, 13(2), 57-77. 